\title{
AI technologies: A key to unlock the door of Omni-channel capabilities
}

\author{
Vidushi $^{1}$ | Dr. R Kashyap ${ }^{2}$ \\ 1, 2 Department of Fashion \& Textiles, IIS University, Jaipur, Rajasthan, India
}

To Cite this Article

Vidushi and Dr. R Kashyap, "AI technologies: A key to unlock the door of Omni-channel capabilities", International Journal for Modern Trends in Science and Technology, 6(9S): 105-115, 2020.

Article Info

Received on 25-August-2020, Revised on 08-September-2020, Accepted on 12-September-2020, Published on 18-September-2020.

\section{ABSTRACT}

The purpose of this paper is to identify the drivers and enablers of using AI technologies in three important areas of Omni-channel retailing-customer experience, data management and supply chain efficiency. This paper also explores the different AI technologies which can be used by retailer to manage the supply chain, data and their engagement with customers. In this era of digitalization, online and offline retailers must come up with unique ways to get people to shop. AI technologies can provide better experience to customers while shopping and in turn improve the efficiency of retailers.

KEYWORDS: AI technologies, Omni-channel retailing, Supply chain management, Customer experience, Data Management

\section{INTRODUCTION}

In this digital era, generation is becoming more tech-savvy due to which every sector has to compete with this digitalization challenge. AI technologies are proving to be a game changer when it comes to digitalizing shopping experience. This technology has been effectively used by retailers to provide a seamless shopping experience to their customers. With the emergence of technologies, customers are changing their shopping behaviour. In order to retain the customers, retailers should become customer oriented rather than product oriented. In providing the better customer experience, retailers are facing a big challenge in determining the technology and strategy.

Now-a-days customers are becoming Omni-channel customers which create the need of understanding the Omni- channel concept. For retailers the initial step is to understand
theOmni-channel initiatives and thetechnology to create this environment. Retailers are more dependent on technologies in order to provide a true Omni-channel services, which will increase customer engagement, loyalty and ultimately sales. In Omni-channel approach, multiple channels (Online and offline) have beenintegrated to offer customers a seamlessshopping experience. AI technologies helps both online and offline retailers to increase their capability to create and optimize customer centric retail experience.

"AI technology is a key to differentiate you from your competitors"

Brendan Witcher, principal analyst at Forrester in his presentation "Hot or not- The (Actual) Top Tech Investments For 2019" defined Omni-channel commerce has three specific segments which are 
customer

andconnectedJourney,productandprice, andfulfill ment capabilities which provides the customer what they want where they want it. [1]

"If you know your customers well, you can easily create Omni-channel environment"

Advanced data analytics and data analysis is needed to provide better customer experience. A retailer can do it more effectively by hiring a data team and by knowing what is going on with their customers. By analyzing the critical data and $\mathrm{f}$. developing predictive insights, retailer can provide the seamless experience to thecustomers.

\section{REVIEW OF LITERATURE}

\section{A. Omni-channelConcept}

Omni-channel retail model integrates all existing channels to offer customers a seamless shopping experience.

Thisretailstrategyblursthedistinctionbetweenphysi caland digital channels by empowering the centralized data management. As a result, customers can simultaneously use different channels for shopping. They can start their journey by searching at a channel and finish the purchase in another one.

\section{B. Navigating towards AItechnology}

AI technology is the path to automate the business $c$. intelligence, reduce manual work and foster cost efficiency which will ultimately impact the customer experience. Retailers can move to the next level with personalization, automation, and increased efficiency by using AI technologies.

\section{Omni- channel capabilities can be improved by Artificial Intelligence}

$\mathrm{AI}$ and machine learning are enhancing Omni-channel strategies by providing insights about the changing need and preference of customers, creating customer journeys and delivering consistent experiences. This retail model will be successful when each touchpoint provides highly personalized experience to the customer. In order to provide better customer experience in real time, AI technologies proves to be beneficial for both retailer as well as to the customers. [2]
This technology defines customer profile, their buying preferences and journeys moreprecisely.

b. Brands can manage Omni-channel pricing by channel preferences, purchase history and price sensitivity.

c. IT infrastructure can be redesigned and integrated to scale customer experiences by Omni-channel retailers.

d. Supply chain can be digitized.

e. On-time performance and faster revenuegrowth can be enabled using AI.

\section{It predicts content which will lead a customer} tobuy.

\section{Artificial Intelligence used by Brands [3]}

a. Tommy Hilfiger's designinspiration

Tommy Hilfiger collaborated with IBM and FIT for a project called REIMAGINE RETAIL. This project is done to explore how AI can enhance design inspiration and improve manufacturing andmarketing

\section{b. Macy's On Call application}

IBM Watson has prepared a shopping assistant powered by AI for in-store shoppers of Macy's. This technology helps customers to get answer to their queries like location of a particular product and stock status etc.

\section{Walmart: Anticipating Customer Needs}

Walmart has tested facial recognition software as an anti- theft mechanism in 2015 to anticipate customer needs and optimize operations. This technology has the ability to recognize the frustration level of customers at checkout. A customer service representative will get an alarm to speak with the frustrated customer.

\section{d. North Face: Robot Sales Associates}

North Face has been using artificial intelligence and machine learning to provide a highly personalized shopping experience. IBM Watson has prepared an application called "Shop with IBM Watson" where shoppers speak into their phone to access the Watson. This technology helps in turning the data information into meaningful customer insights that will enhance digital shoppingexperience.

\section{METHODOLOGY}


This study adopts an exploratory approach to exploreand identify the AI technologies which will enhance the Omni- channelexperience.

\section{Data collection and analysis-}

A pilot study has been conducted through survey using questionnaire to identify the awareness of Omni-channel concept and AI technologies. Also, area where this technology will prove to be beneficial for smooth workingof Omni-channel retail model has been identified. A sample of 10 retailers has been used for response collection. Secondary data has been collected by analysis of documents, case studies, reports and published articles. Percentage has been used as analysistechnique.

\section{RESULTS ANDDISCUSSIONS}

In general, the study showed that retailers are aware

Omni-channelconceptandAItechnologies.However, dueto some limitation, they are not using thistechnology.

\section{Omni-channel concept}

Q1. Which channels do you currently use for product selling? (Check all that apply)

Retailers are using different channels for product selling. However, $90 \%$ of retailers sell products through Brick \& Mortar store.

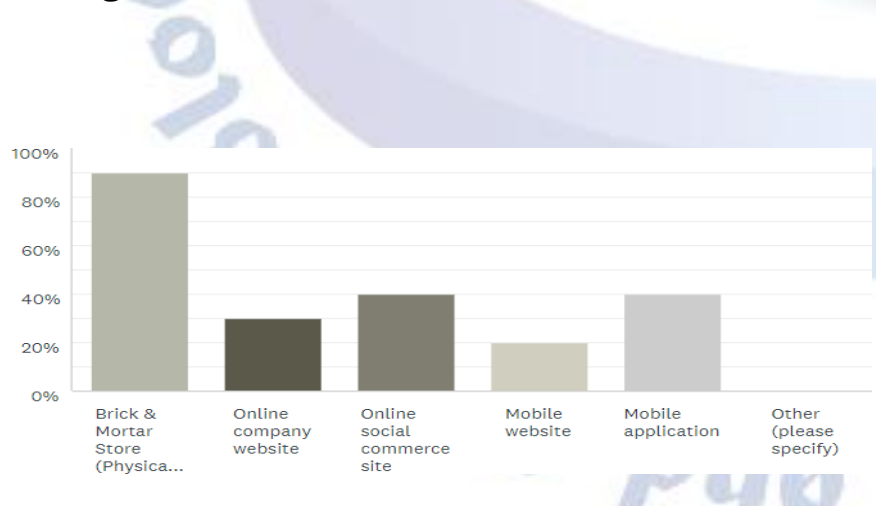

Fig. 1. Channels used by retailers

Q2. Are you aware of Omni-channel retailing?

$80 \%$ of retailers are aware of Omni-channel retailing.

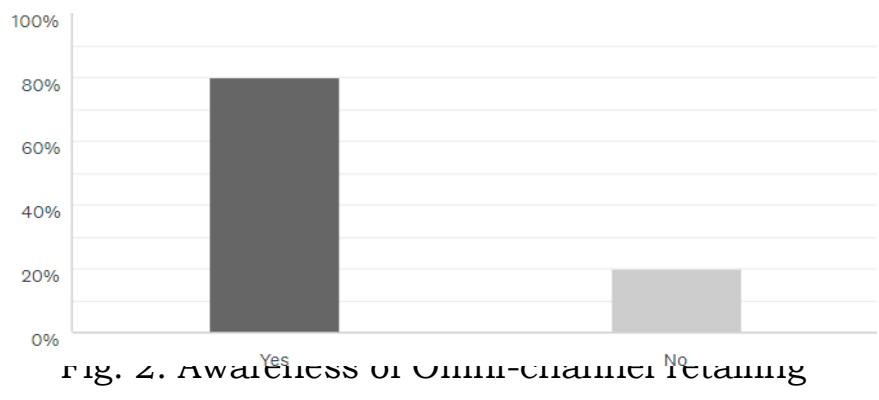

Q3. What are the most important objectives of your organization's Omni-channel strategy? (Check top three)

$90 \%$ of retailers say creating a seamless customer experience across all channels is the most important objective of their organization's Omni-channel strategy.

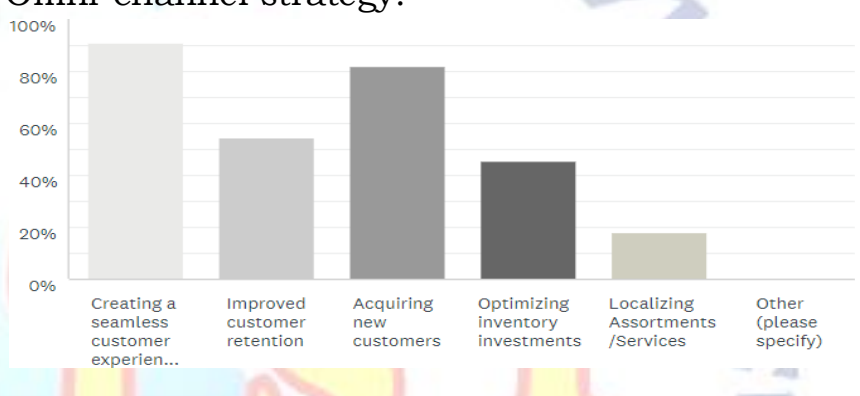

Fig. 3. Objective of Omni-channel strategy

Q4. What challenges are you facing in implementing Omni- channel strategy? (Check top three)

$70 \%$ of retailers say customer experience and data management and $60 \%$ retailers say supply chain management are the major challenges they are facing in implementing Omni-channel strategy.

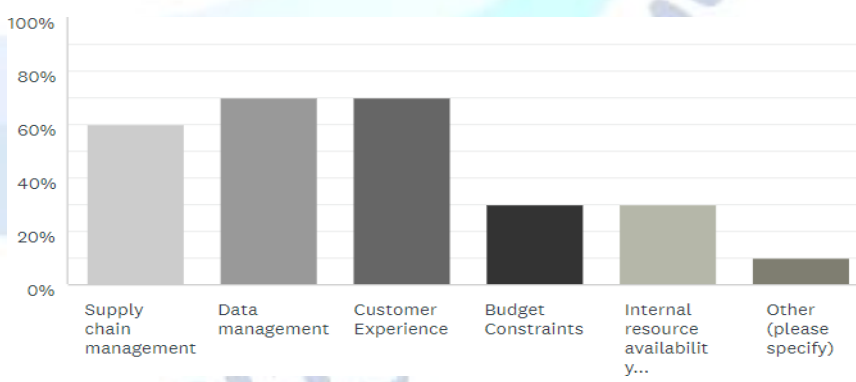

Fig. 4. Challenges of Omni-channel strategy

\section{AI Technology}

Q5. Have you ever used any AI technology? If yes, then please specify

$10 \%$ of retailers say they have used Google as AI technology. This shows that exposure to different AI technologies is must for retailers. 
Table I. Use of AI Technology

\begin{tabular}{|c|c|}
\hline Yes & $10 \%$ \\
\hline No & $90 \%$ \\
\hline No, but plan to add & $0 \%$ \\
\hline
\end{tabular}

Q6. Which technologies will be beneficial for Omni-channel strategy? (Check all that apply)

$80 \%$ of retailers say Sensors/Internet of things, $70 \%$ of retailers say Virtual personal assistants and $60 \%$ of retailers say Speech/Audio analytics and Image analytics are the most important technology which will be beneficial for Omni-channel strategy.
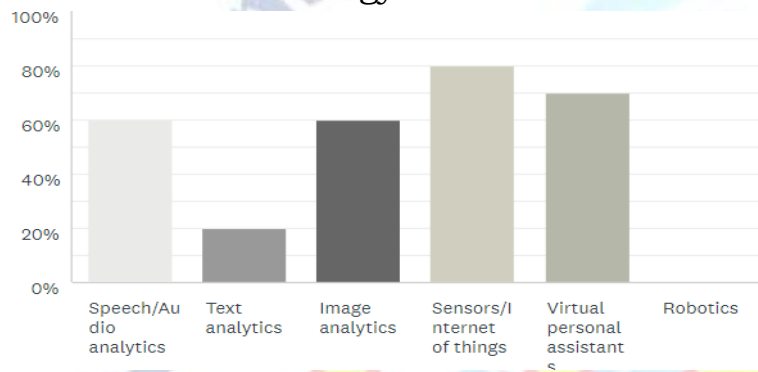

Fig. 5. AI Technologies for Omni-channel strategy

Q7. What reasons drive your organization to invest in AI technologies? (Check all that apply)

$80 \%$ of retailers say more personalized customer experience, $60 \%$ of retailers say data management and $50 \%$ of retailers say Supply chain efficiency and customer analytics are the major reasons to invest in AI technologies.

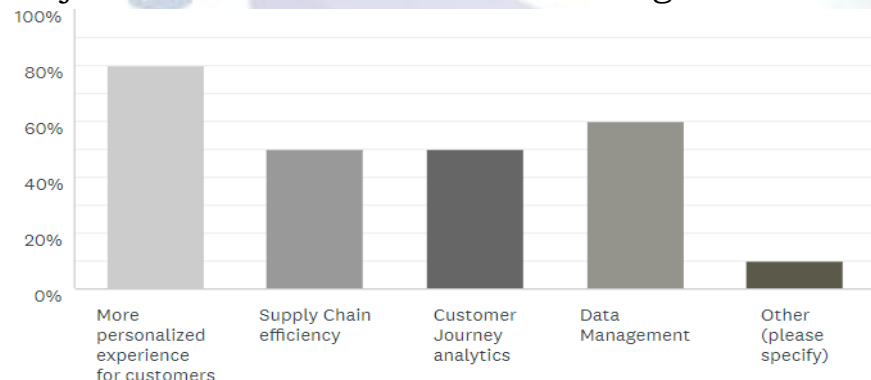

Fig. 6. Reasons to invest in AI Technologies

Q8. What reasons have been holding you back from implementing AI technologies? (Check all that apply)

$70 \%$ of retailers say concerns about integration into

existingsystemisthemajorreasonwhichhavebeenh olding them back from implementing AItechnologies.
This survey showed that retailers are facing difficulties in customer experience, supply chain and data management. Hence, a 3-dimensional structure has been prepared for retailers to overcome these challenges. This structure will provide benefits of using AI technologies in these three important areas of Omni-channelretailing.

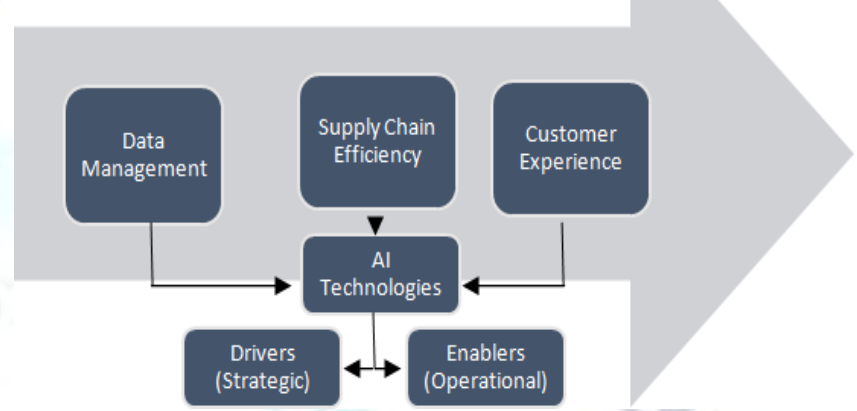

Fig.8.3-Dimensional Structure of Omni-channel strategy

\section{E. CustomerExperience}

Customer Experience is a key competitive differentiator for retailers. It is difficult for many retailers to maintain the rising and changing customer expectations. Hence, AI technologies help them to meet and exceed customer's expectation through highly personalized experience.

a) AI Technologies:

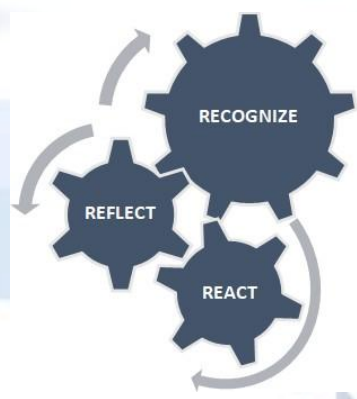

Fig. 9. AI Technologies used for Customer Experience

Retailers can use AI technologies to provide consistent and personalized experience to customer in order to enhance satisfaction, engagement and conversions. In this study, three parameters have been used to define the AI technologies which are beneficial for CustomerExperience. 


\section{R's of AI technology:}

Various AI technologies have been identified for providing better customer experience and divided under three areas- Recognize, Reflect and React.

\section{1) Recognize:}

Facial Recognition: This technology is used to identify or verify the identity of a person using their face. Process of facial recognition includes face detection, capture and match.

Detection: Locates and detects human faces inimages and videos.

Capture: Conversion of analog information (aface) into digital information (data) based on theperson's facial features takes place.

Match: If two faces belongs to the same humanbeing is verified in the matching process. [4]

This technology offers insights into the consumer's buying decision process by identifying individuals and their buying habits which will in turn builds customized experience for them. [5]

Table II. Positive and Negative of Facial Recognition Technology [6]

\begin{tabular}{|l|l|}
\hline \multicolumn{1}{|c|}{ Positive } & \multicolumn{1}{c|}{ Negative } \\
\hline $\begin{array}{l}\text { Improved security } \\
\text { levels }\end{array}$ & $\begin{array}{l}\text { Data processing and } \\
\text { storing is difficult }\end{array}$ \\
\hline Integration is easy & $\begin{array}{l}\text { Problems with image } \\
\text { size and quality }\end{array}$ \\
\hline $\begin{array}{l}\text { Accuracy avoids false } \\
\text { identification }\end{array}$ & $\begin{array}{l}\text { Camera angle should } \\
\text { be correct }\end{array}$ \\
\hline
\end{tabular}

Alibaba $\mathrm{x}$ Guess pop-up in Hong Kong use gyro-sensors which scans the customer's face to observe customer behaviour like what garments, colours and patterns they touched the most. [7]

Speech Recognition: This technology is used to

\begin{tabular}{|l|l|}
\hline \multicolumn{1}{|c|}{ Positive } & \multicolumn{1}{|c|}{ Negative } \\
\hline $\begin{array}{l}\text { Recognize image through } \\
\text { a camera system }\end{array}$ & $\begin{array}{l}\text { Huge availability of data } \\
\text { makes it difficult to } \\
\text { process }\end{array}$ \\
\hline $\begin{array}{l}\text { Identify what customer } \\
\text { likes the most and what } \\
\text { not }\end{array}$ & $\begin{array}{l}\text { Difficult in interpreting } \\
\text { the model }\end{array}$ \\
\hline $\begin{array}{l}\text { Helps in predicting } \\
\text { the customer } \\
\text { behaviour while }\end{array}$ & $\begin{array}{l}\text { Development takes } \\
\text { longer time which will in } \\
\text { turn reduce the } \\
\text { flexibility of the } \\
\text { technology }\end{array}$ \\
\hline buying the product
\end{tabular}

identify words and phrases in spoken language and convert them to a machine-readable format. This technology works on algorithms produced by acoustic and language modeling.

Acoustic Modeling: Presents the relation between linguistic units of speech and audio signals.

Language Modeling: Verifies sounds with word sequences in order to differentiate words that soundsimilar.

This technology is used in call routing, speech-to-text processing, voice dialing and voice search. Siri and Alexa are the two speech recognition technologies used in India. [8]

Table III. Positive and Negative of Speech Recognition Technology

\begin{tabular}{|l|l|}
\hline \multicolumn{1}{|c|}{ Positive } & \multicolumn{1}{|c|}{ Negative } \\
\hline $\begin{array}{l}\text { Easy to use and readily } \\
\text { available }\end{array}$ & $\begin{array}{l}\text { Due to variations of } \\
\text { pronunciation, this } \\
\text { technology is unable to } \\
\text { capture words }\end{array}$ \\
\hline
\end{tabular}

Act as time saver for Unable to sort through those who are not good at background noise typing

Easily installed in Lead to inaccuracies computer and mobile devices

Image Recognition: This technology identifies and detects an object in a digital image or video. Process of Image recognition includes gather and organize data, build a predictive model and use it to recognizeimages.

Gather and organize data: Computer interprets the image as raster or vector based then identifies the important data in the image and break down into distinct objects to be analyzed andretained.

Build a predictive model: Learning algorithms processes the object and collected images and then sort them into separate classes of similar image types.

Use it to recognize images: Image data has been collected, organized and recognized which will in turn identify different classes of image and similar objects in the new images. [9]

This is used to verify and analyze customers and their opinions.

Table IV. Positive and Negative of Image Recognition Technology [10] 
data to deliver benefits like interpreting multiple

Machine Learning Platforms: This platform is a kind of algorithm which can receive input data and convert it into output data through statistical analysis. Process of machine learning includes various types of automated algorithms which learn to model functions and predict future actions from data.

Virtual assistant is an example of machine learning platform which combine deep learning models to interpret natural speech, bring in relevant context and take an action. This technology is used for prediction and classification. [11]

Table V. Positive and Negative of Machine Learning Platforms

\begin{tabular}{|l|l|}
\hline \multicolumn{1}{|c|}{ Positive } & \multicolumn{1}{|c|}{ Negative } \\
\hline $\begin{array}{l}\text { Identify the available data } \\
\text { and solve theproblems }\end{array}$ & $\begin{array}{l}\text { Take time and resources } \\
\text { to bring results }\end{array}$ \\
\hline $\begin{array}{l}\text { Learn complex decision } \\
\text { system, find patterns and } \\
\text { anomalies in data as well } \\
\text { as raise alerts if needed } \\
\text { susceptibility [13] } \\
\text { [12] }\end{array}$ & \\
\hline $\begin{array}{l}\text { Identify trends and } \\
\text { patterns }\end{array}$ & $\begin{array}{ll}\text { Interpretation of results } \\
{[14]}\end{array}$ \\
\hline
\end{tabular}

Deep Learning Platforms: This technology can imitate the human brain, processing data and create patterns for decision making. This is used t $§$ ) recognize patterns and classify applications.[15]

Table VI. Positive and Negative of Deep Learning Platforms

\begin{tabular}{|l|lr|}
\hline \multicolumn{1}{|c|}{ Positive } & \multicolumn{2}{|c|}{ Negative } \\
\hline $\begin{array}{l}\text { Create more personalized } \\
\text { e-learning experiences }\end{array}$ & $\begin{array}{l}\text { Requires human to } \\
\text { monitor it }\end{array}$ \\
\hline $\begin{array}{l}\text { Allow system to process, } \\
\text { learn and handle large } \\
\text { amount of data }\end{array}$ & $\begin{array}{l}\text { on deep learning } \\
\text { platforms can inherit } \\
\text { and perpetuate covert } \\
\text { and overtbiases }\end{array}$ \\
\hline $\begin{array}{l}\text { Due to increase demand of } \\
\text { this technology, costs are } \\
\text { anticipated to decrease. }\end{array}$ & \begin{tabular}{ll} 
initiate it human to \\
\hline
\end{tabular} \\
\hline
\end{tabular}

React:

Natural Language Generation: This technology converts the audio signals into text and uses that

\begin{tabular}{|l|l|}
\hline \multicolumn{1}{|c|}{ Positive } & \multicolumn{1}{|c|}{ Negative } \\
\hline $\begin{array}{l}\text { Helps in improving } \\
\text { customer satisfaction }\end{array}$ & $\begin{array}{l}\text { Works only if you have } \\
\text { system that can support } \\
\text { full speech recognition } \\
\text { and interaction }\end{array}$ \\
\hline $\begin{array}{l}\text { Helps in understanding } \\
\text { customer needs }\end{array}$ & $\begin{array}{l}\text { Define sentence in a } \\
\text { parsed way in different } \\
\text { ways }\end{array}$ \\
\hline $\begin{array}{l}\text { Automatic } \\
\text { produced } \\
\text { structured data }\end{array}$ & text \\
\hline
\end{tabular}

languages and dialects [12]. This enables computers to communicate ideas with more accuracy. Process of Natural language generation includes text realization, text and sentence planning.

Text Planning: Order of content in structured data

Sentence Planning: Combine sentences to present the flow ofinformation

Text Realization: Represent text

This technique is used in generating customer service reports and market summaries.[17]

Table VII. Positive and Negative of Natural Language

Generation

Driver and Enabler of CustomerExperience:

Table VIII. Driver and Enabler of Customer Experience

\begin{tabular}{|c|c|}
\hline Driver & Enabler \\
\hline $\begin{array}{l}\text { Predicts } \\
\text { experiences }\end{array}$ & $\begin{array}{l}\text { Anticipate future needs ofcustomer } \\
\text { Analyze behavioral patterns, } \\
\text { market trends and user experiences } \\
\text { for proactive measures to secure a } \\
\text { personalized experience across } \\
\text { multiple channels[18] }\end{array}$ \\
\hline $\begin{array}{l}\text { Convert } \\
\text { surveys int } \\
\text { conversation }\end{array}$ & $\begin{array}{l}\text { Modern surveys allow customers to } \\
\text { give feedback in new, robust and } \\
\text { intuitive ways through enhancing } \\
\text { audio comments or image or } \\
\text { videoupload } \\
\text { Organization can engage in a } \\
\text { dialogue, using follow- up } \\
\text { questions, apologies orinformation }\end{array}$ \\
\hline
\end{tabular}

Measure how AI detects emotions which strongly customers affect the customerloyalty 


\begin{tabular}{|c|c|}
\hline el & $\begin{array}{l}\text { Measure emotion signals lif } \\
\text { neurophysiological reactions an } \\
\text { social-expressive behaviors[19] }\end{array}$ \\
\hline $\begin{array}{l}\text { rovide } \\
\text { sights from } \\
\text { nages and } \\
\text { deos }\end{array}$ & $\begin{array}{l}\text { Customers use images and vided } \\
\text { to interact with the brand. }\end{array}$ \\
\hline $\begin{array}{l}\text { Deliver } \\
\text { seamless } \\
\text { experience }\end{array}$ & $\begin{array}{l}\text { Provide more pertinent } \\
\text { information/offers that are more } \\
\text { relevant for thecustomers. } \\
\text { Enhance engagement which will in } \\
\text { turn provide more accuratedata }\end{array}$ \\
\hline $\begin{array}{l}\text { Opens new } \\
\text { route of } \\
\text { personalized } \\
\text { experience }\end{array}$ & $\begin{array}{l}\text { Build a more interactive an } \\
\text { personalized customer experien } \\
\text { through recognition technologies } \\
\text { place orders and access }\end{array}$ \\
\hline $\begin{array}{l}\text { Enhance } \\
\text { service } \\
\text { environments }\end{array}$ & $\begin{array}{l}\text { Reduce human interaction an } \\
\text { streamline services }\end{array}$ \\
\hline Connects & $\begin{array}{l}\text { Centralize the data and insight } \\
\text { and build a holistic pictur } \\
\text { ofcustomer } \\
\text { Anticipate needs and proactive } \\
\text { intervene to keep the customerloy }\end{array}$ \\
\hline $\begin{array}{l}\text { Optimizes } \\
\text { data }\end{array}$ & $\begin{array}{l}\text { Use data for insights abol } \\
\text { customerpreferences } \\
\text { Use technologies like chatbots } \\
\text { provide personal and tru } \\
\text { exceptionalexperience }\end{array}$ \\
\hline $\begin{array}{l}\text { Supports } \\
\text { product } \\
\text { discovery }\end{array}$ & $\begin{array}{l}\text { Adopt intelligent AI base } \\
\text { technologies to engage mor } \\
\text { effectively with theircustomers } \\
\text { AI powered strategies like visua } \\
\text { search, discovery an } \\
\text { recommendations help consumer } \\
\text { search more efficiently for relevan } \\
\text { products andupliftingconversion }\end{array}$ \\
\hline
\end{tabular}

\section{F. Supply Chain Efficiency}

Right product, in the right place, at the right time has always been challenging to achieve. AI technologies have been used in this direction to provide a unified brand experience and frictionless fulfillment across all channels which in turn fulfill the objective of Omni-channel strategy.

\section{AI Technologies:}

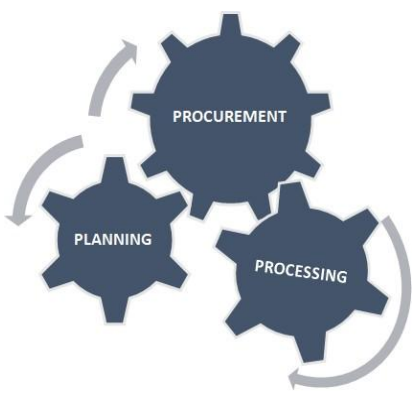

Fig. 10. AI Technologies used for Supply Chain Efficiency

Retailers can improve forecasting, visibility across all channels and predictive capabilities through AI technologies which will in turn enhance the supply chain efficiency. Inthis study, three parameters have been used to define the AI technologies which are beneficial for Supply Chain Efficiency.

\section{P's of AI technology:}

Various AI technologies have been identified for effective and efficient supply chain and divided under three areas- Procurement, Planning and Processing.

\section{1) Procurement:}

Chatbot: This technology can simulate a conversation with a user in natural language through messaging applications, website, mobile applications or phone. Automation and augmentation of Chabot capability helps in streamline procurement related tasks. Process of Chatbot includes user request analysis and returning the response.

This is used for conversation with supplier, place purchasing requests, answer questions related to procurement functionalities and documentation. [20]

Table IX. Positive and Negative of Chatbot Technology

\begin{tabular}{|l|l|}
\hline \multicolumn{1}{|c|}{ Positive } & \multicolumn{1}{c|}{ Negative } \\
\hline $\begin{array}{l}\text { Streamline interactions } \\
\text { between people and } \\
\text { services }\end{array}$ & Limited responses \\
\hline $\begin{array}{l}\text { Improve operational } \\
\text { efficiency }\end{array}$ & Limited database \\
\hline $\begin{array}{l}\text { Improve customer } \\
\text { engagement process }\end{array}$ & $\begin{array}{l}\text { Complex chatbots are } \\
\text { expensive }\end{array}$ \\
\hline
\end{tabular}


2) Planning:

Machine Learning:

- Supply chain planning: This technology helps in forecasting within inventory, demand and supply. Revolutionize agility and automation of supply chain decision- making. It helps in optimizing the delivery of goods while balancing supply and demand.

- Warehouse management: This technology reshapes the warehouse management through constantlyself- improvingoutput.

Machine learning and Predictive Analytics:

- Supplier selection and Supplier relationship management: Machine learning and predictive analytics are used for supplier selection and relationship management. Predictive analytics create models which are used to examine existing data and trends to understand customers and products while identifying future opportunities and risks.

Machine learning and predictive analytics make the supplier selection more intelligible. It helps in selection and sourcing from the right supplier. With the help of machine learning andintelligible algorithms, gathered data would provide better outputs.

3) Processing:

Natural language processing: This technology streamline large amount of data, build data setsregarding suppliers information for auditing and compliance actions.

Driver and Enabler of Supply ChainEfficiency:

Table X. Driver and Enabler of Supply Chain Efficiency

\begin{tabular}{|l|l|}
\hline Driver & Enabler \\
\hline Contextual & $\begin{array}{l}\text { Reduce the operating costs and } \\
\text { Intelligence } \\
\text { manageinventory } \\
\text { Identify damage and carry out } \\
\text { needed actions through AI } \\
\text { powered visualinspection } \\
\text { Sort palletized shipments, parcels } \\
\text { and letters through Intelligent } \\
\text { Robotic Sorting[22] }\end{array}$ \\
\hline $\begin{array}{l}\text { Offers } \\
\text { insights }\end{array}$ & $\begin{array}{l}\text { Combines the capabilities of } \\
\text { different technologies like machine }\end{array}$ \\
\hline
\end{tabular}

\begin{tabular}{|c|c|}
\hline vity & $\begin{array}{l}\text { learning } \text { and reinforcement } \\
\text { learning tofind the factors and } \\
\text { issues which affects the } \\
\text { performance of the supply chain }\end{array}$ \\
\hline forecasting & $\begin{array}{l}\text { Measure and track all the factors } \\
\text { which can work towards offering } \\
\text { accuracy in demandforecasting } \\
\text { Provide continuous forecasts } \\
\text { based on real time sales and } \\
\text { otherfactors }\end{array}$ \\
\hline $\begin{array}{l}\text { Estab } \\
\text { end- } \\
\text { jisibi }\end{array}$ & $\begin{array}{l}\text { Capture, process and utilize } \\
\text { structured and unstructured data } \\
\text { to provide real time visibility [23] }\end{array}$ \\
\hline $\begin{array}{l}\text { ry } \\
\text { ement }\end{array}$ & $\begin{array}{l}\text { Create control towers to centralize } \\
\text { data and decision-making } \\
\text { Enhance the computer vision } \\
\text { capabilities of ERP systems and } \\
\text { machines which enables more } \\
\text { accurate inventorymanagement }\end{array}$ \\
\hline $\begin{array}{l}\text { Create new } \\
\text { performance } \\
\text { engines }\end{array}$ & $\begin{array}{l}\text { These engines automate the } \\
\text { execution of supply chain } \\
\text { functions, as well as } \\
\text { optimizetransactions } \\
\text { Determine the impact on key } \\
\text { performance indicators (KPIs) and } \\
\text { make immediate supply chain } \\
\text { decisionstooptimize financial } \\
\text { results }\end{array}$ \\
\hline $\begin{array}{l}\text { Managing } \\
\text { through agile } \\
\text { decision- } \\
\text { making }\end{array}$ & $\begin{array}{l}\text { Collaborative, data driven and } \\
\text { platform based management } \\
\text { model share qualitative } \\
\text { information and real time data } \\
\text { from the supply chain systems, } \\
\text { review and } \\
\text { discussimplications } \\
\text { Create resolution options, share } \\
\text { with stakeholders, discuss on the } \\
\text { collaborative platform andtake } \\
\text { immediate action }\end{array}$ \\
\hline $\begin{array}{l}\text { Develop } \\
\text { personalized } \\
\text { and flexible } \\
\text { approach }\end{array}$ & $\begin{array}{l}\text { Create segmentation strategies } \\
\text { which indicate consumers } \\
\text { personalized needs by channel, } \\
\text { service level andlocality } \\
\text { Real-time visibility will produce } \\
\text { greater insight, variation, and } \\
\text { urgency of understanding and } \\
\text { meeting demand requirements } \\
\text { Develop multiple supply chain } \\
\text { models for a single, integrated } \\
\text { network to empower the } \\
\text { supplychain organizations }\end{array}$ \\
\hline
\end{tabular}




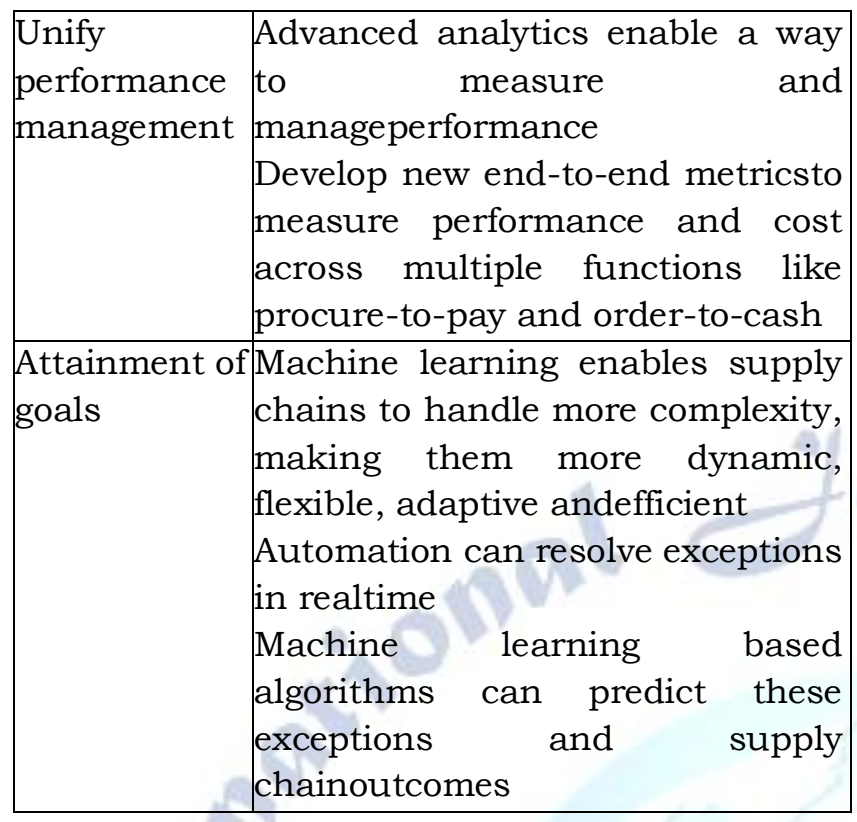

\section{G. Data Management}

Data management is a time consuming task. With the help of AI technologies, retailers can save the time of their employees and engage them in other tasks. It

possibleformachinestolearnfromexperience,adjust tonew inputs and perform human-liketasks through AI.

a) AI Technologies:

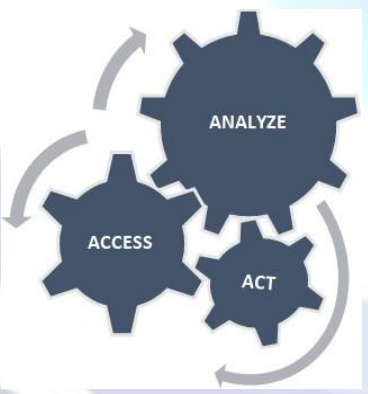

Fig. 11. AI Technologies used for Data Management

3A's of AI Technology:

Various AI technologies have been identified for managing data and divided under three areasAnalyze, Access and Act.

\section{1) Analyze:}

Augmented Analytics: This technology use AI and machine learning to transform how analytics content is developed, consumed and shared.

NLP/Conversation Analytics: This technology is used to analyze complex combination of data and to make analytics accessible to everyone in the organization.

\section{2)Access:}

Data Fabric: This technology enables frictionless access and sharing of data in a distributed data environment. It enables a single and consistent data management framework. Seamless data access will be allowed while using thistechnology.

3)Act:

Continuous Intelligence: This technology use real time context data to improve decisions. It is a design pattern in which real time analytics are integrated which process current and historicaldata to prescribe actions. It provides decision automation and decision support. [24]

b) Driver and Enabler of Data Management[25]:

Table XI. Driver and Enabler of Data Management

\begin{tabular}{|c|c|}
\hline Driver & Enabler \\
\hline $\begin{array}{l}\text { Automate } \\
\text { routine }\end{array}$ & $\begin{array}{lrr}\text { Automate } & \text { routine } & \text { data } \\
\text { management } & \text { tasks } & \text { like }\end{array}$ \\
\hline dataprocessin & dataintegration \\
\hline & $\begin{array}{l}\text { Create automated rules for } \\
\text { processingdata }\end{array}$ \\
\hline $\begin{array}{l}\text { Discover data } \\
\text { qualityissues }\end{array}$ & $\begin{array}{l}\text { Check data for qualityissues } \\
\text { Make correctionautomatically }\end{array}$ \\
\hline $\begin{array}{l}\text { Include } \\
\text { legacy data }\end{array}$ & $\begin{array}{l}\text { Process legacy data which } \\
\text { presently exists in offline format } \\
\text { through NLP and AI image } \\
\text { recognition } \\
\text { Convert images of old documents } \\
\text { tomachinereadable text and } \\
\text { accumulate these in data stores } \\
\text { for further processing }\end{array}$ \\
\hline $\begin{array}{l}\text { Develop new } \\
\text { data rules }\end{array}$ & $\begin{array}{l}\text { Analyze data usage patterns and } \\
\text { recommend the optimal strategies } \\
\text { for collection and retention }\end{array}$ \\
\hline $\begin{array}{l}\text { Prioritizing } \\
\text { and } \\
\text { securingdata }\end{array}$ & $\begin{array}{l}\text { Collect data and put it to gooduse } \\
\text { Secure the dataproperly }\end{array}$ \\
\hline Sorting & $\begin{array}{l}\text { Machine learning and algorithms } \\
\text { sort and } \\
\text { handle different types of emails, } \\
\text { documents and images etc. }\end{array}$ \\
\hline
\end{tabular}

\section{CONCLUSION}

Retailers may have different perspective and motivation to move towards Omni-channel retailing. However, they are facing various difficulties in implementation of this strategy. As a theoretical contribution, this study identifies a set ofdriversandenablersforOmni-channelretailingand classifies them under three areas- Customer 
Experience, Supply chain efficiency and Data management. This study explores the AI technologies which will help the retailer for providing better customer experience, data management and supply chain efficiency.

In light of the findings, the following recommendations for retailers to adopt Omni-channel retailing are made:

- Retailers should focus more on customer engagement as they interact with your brand through a number of platforms like website, application, physicalstore, kiosketc. Theyexpectto start their journey on one platform and continue it on another seamlessly. Consumers are becoming Omnipresent, you need to adopt new technologies to enhance engagementstrategies.

- Retailers should develop a centralized and integratedsupplychainprocesswithproperdemand forecasting in order to prevent the overstock and understock problem. With the help of various analytics, retailers can improve their supply chain efficiency.

- Data management is a time consuming task and itis difficult for analytics team to do it in a real time. Hence,various AI technologies can be used to manage the data effectively which will in turn become base for making differentstrategies.

This study provides a three dimensional structure to retailers which they can refer before implementing AI technologies for their Omni-channel strategy. However, this study has few limitations. Future research could test the findings in a broader research context with a bigger and diversified sample. The scope of this study is primarily confined to discover the driver and enablers for retailers for adopting AI technologies. Further studies could explore the barriers and inhibitors of AI technologies.

\section{REFERENCES}

[1] J. Mottl, "Knowing the difference between must-have CX technologies and what can wait," May 3, 2019. [Online]. Available:

https://www.retailcustomerexperience.com/articles/kno wing-the-

difference-between-must-have-cx-technologies-and-whatcan-wait/. [Accessed May 9,2020].

[2] L. Columbus, "10 ways AI \& Machine Learning are Revolutionizing Omnichannel," Forbes, February 17, 2019. [Online]. Available: https://www.forbes.com/sites/louiscolumbus/2019/02

\section{/17/10-ways-ai-}

machine-learning-are-revolutionizing-omnichannel/ \#230 0331d1181. [Accessed May 02,2020]

[3] C. Trotter, "50 Best AI Retail Application," April 12, 2018. [Online]. Available:

https://www.insider-trends.com/50-best-ai-retail-appli cations/. [Accessed May 20,2020].

[4] "The top 7 trends for facial recognition in 2019," Gemalto, May 12, $2019 . \quad$ [Online].

Available:https://www.gemalto.com/govt/biometrics/f acial-recognition. [Accessed May 13,2020].

[5] M. Smith, "Top 5 Retail Technology Trends Making Waves In 2019,” 2019.2 [Online]. Available:https://www.fibre2fashion.com/industry-articl e/8282/top-5-retail-technology-trends-making-waves-in2019. [Accessed May 14, 2020].

[6] "Pros and Cons of Facial Recognition Technology For Your Business," TecSynt Solutions, December 27, 2017. [Online].

Available:https://www.upwork.com/hiring/for-clients/p ros-cons- facial-recognition-technology-business/. [Accessed April 29,2020].

[7] M. Mcdowell, "Stores get smart about AI," March 12, 2019. [Online].

Available:https://www.voguebusiness.com/technology/a rtificial- intelligence-physical-stores-kering-nike-alibaba. [Accessed May 12, 2020].

[8] M. Rouse and K. Kiwak, "Speech Recognition," December, 2016. [Online]. Available:

https://searchcustomerexperience.techtarget.com/definition/ speech-recognition. [Accessed May 11, 2020].

[9] "How image recognition will transform businesses," New Generation Applications Pvt. Ltd., Jan 15, 2019. [Online]. Available:

https://www.newgenapps.com/blog/how-image-recognit ion-will- transform-businesses. [Accessed May 19,2020].

[10] S. Gupta, "Understanding Image Recognition and its uses," September 28, 2018. [Online].

Available:https://www.einfochips.com/blog/understan ding-image-recognition- and-its-uses/. [Accessed May 01,2020].

[11] M. Rouse, "Machine Learning (ML)," May, 2018. [Online]. Available:https://searchenterpriseai.techtarget.com/defin ition/machine-learning-ML. [Accessed May 16, 2020].

[12] “Top 15 Artificial Intelligence Platforms," PAT Research, 2018. [Online]. Available:

https://www.predictiveanalyticstoday.com/artificial-intel ligence-platforms/. [Accessed May 11, 2020].

[13] "What are the pros and cons of Machine Learning?," Seven Tablets.

[Online].

Available:https://seventablets.com/blog/what-are-the-p ros- and-cons-of-machine-learning/. [Accessed May $12,2020]$.

[14] "Advantages and Disadvantages of Machine learning language," Dataflair Team, March 1, 2019. [Online]. Available:https://data-

flair.training/blogs/advantages-and-disadvantages-of-m achine- learning/. [Accessed May 15,2020].

[15] “19 Artificial Intelligence Technologies to look for in 2019," Adext AI, $2019 . \quad$ [Online]. Available:https://blog.adext.com/artificialintelligence-technologies-2019/. [Accessed May 10,2020].

[16] K. Creighton, "The Pros and Cons of Implementing Deep-Learning AI," November 29, 2018. [Online].Available:

https://lddailyadvisor.blr.com/2018/11/the-pros-and-c ons-of-implementing-deep-learning-ai/. [Accessed May, 
10, 2020].

[17] "What is Natural Language Processing in Artificial Intelligence," Dataflair Team, November 15, 2018. [Online]. Available:https://data-

flair.training/blogs/ai-natural-language-processing/ . [Accessed May 10,2020].

[18] D. Roe, "10 Ways AI helps improve customer Experiences," April 24, 2018. [Online]. Available:https://www.cmswire.com/customerexperience/10-ways-ai-helps-improve-customer-experien ces/. [Accessed May 12,2020].

[19] "Optimize customer experience metrics with 12 AI-enabled use cases," Forrester Research Inc., 2019. [Online].

Available:https://tdwi.org/whitepapers/2019/04/adv-all -ibm-optimize-customer-metrics-with-ai-use-cases.aspx. [Accessed May 15,2020].

[20] S. Jenks, "6 Application of Artificial Intelligence for your Supply Chain,” October 26, 2017. [Online].

Available:https://medium.com/@KodiakRating/6-appli cations-of-artificial-

intelligence-for-your-supply-chain-b82e 1e 7400c8.

[Accessed May 10,2020].

[21] "What are the Pros and Cons of Chatbots?," APAC CIO Outlook, December 3, 2018. [Online].

Available:https://www.apacciooutlook.com/news/what -are-the-pros-and-cons- of-chatbots-nwid-5503.html. [Accessed May 02,2020].

[22] K. Pndey, "How AI is revolutionizing Global logistics and Supply Chain Management," April 15, 2019. [Online]. Available:

https://readwrite.com/2019/04/15/how-ai-is-revolutio nizing-global- logistics-and-supply-chainmanagement/. [Accessed May 10,2020].

[23] M. Hajibashi, "Reinventing the Supply Chain with AI," October 4, 2018. [Online]. Available:

https://www.accenture.com/us-en/insights/artificial-i ntelligence/reinventing-the-supply-chain. [Accessed May 10,2020].

[24] S. Moore, "Gartner Identifies Top 10 Data and Analytics Technology Trends for 2019," February 18, 2019. [Online]. Available:

https://www.gartner.com/en/newsroom/press-releases /2019-02-18-

gartner-identifies-top-10-data-and-analytics-technolo.

[Accessed May 12,2020].

[25] P. Kowalke, "5 Opportunities for Managing Data with AI," January, 2019. [Online].

Available:https://it.toolbox.com/blogs/peterkowalke/ 5 -opportunities-for- managing-data-with-ai-011419. [Accessed May 10,2020]
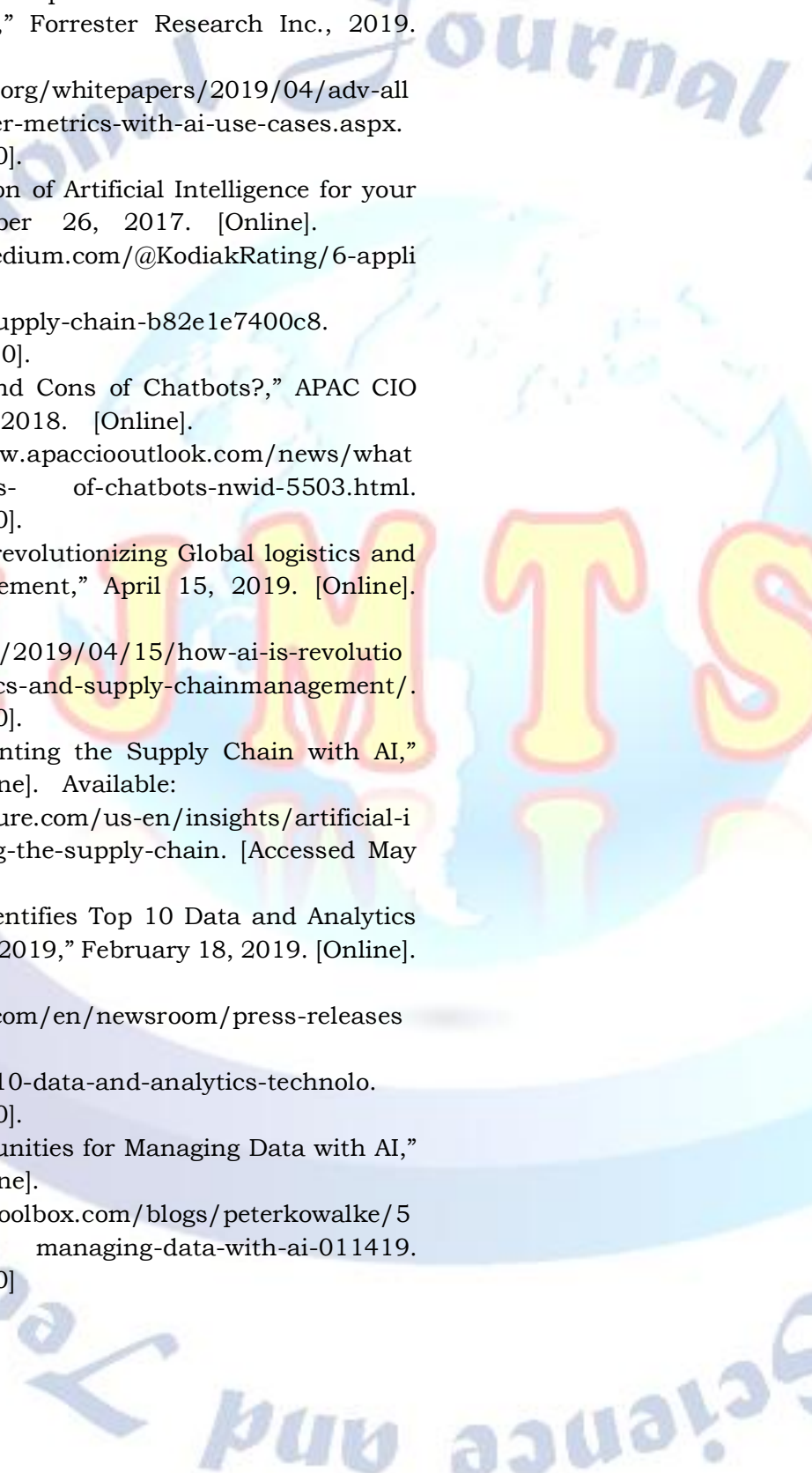